\title{
Analisa Setting Rele Differensial Pada Generator PT. PJB UBJ O \& M PLTU Rembang
}

\author{
Ibnu Hajar'; Maharani Ratna Mercury² \\ 1,2 Departemen Teknik Elektro, STT PLN Jakarta \\ 1ibnu.hajar@sttpln.ac.id
}

\begin{abstract}
PT PJB UBJ O\&M Rembang PLTU is one of the Java Bali steam power plants, which the output that produced by the Rembang PLTU generator is $315 \mathrm{MW}$. Generator is the core equipment of system which has different of operating characteristics and protection systems. Disturbances in generators include damage to generators or auxiliary devices, single-phase short circuit current, three-phase short-circuit current and imperfect electrical contacts. To avoid such interferences, a protection system is needed, one of which uses differential relay. This device works very fast and does not require time delay by detecting the difference in the current entering the stator coil, if the current accross on the stator coil is different then the differential relay will work. The purpose of this study is to analyze the differential relay settings on generators installed at PT PJB UBJ O\&M Rembang PLTU which affect the reliability of the generator. The method used in this study is a quantitative method, where in this method a research approach is widely demanded to use numbers from data collection, processing of data, and appearance of the results. The relay setting obtained from this study is $0.1804 \mathrm{~A}$, which means it is still in good condition, so it can carry out its duties as a protection system.
\end{abstract}

Keywords: Generator, Differential Relay, Short Circuit, Protection System

\begin{abstract}
ABSTRAK
PT PJB UBJ O\&M PLTU Rembang merupakan salah satu pembangkit listrik tenaga uap Jawa Bali, dimana output yang dihasilkan generator PLTU Rembang sebesar 315 MW. Generator merupakan peralatan utama dari sistem pembangkitan yang memiliki karakteristik pengoperasian dan sistem proteksi yang berbeda. Gangguan pada generator diantaranya kerusakan generator atau alat bantu generator, arus hubung singkat satu fasa, arus hubung singkat tiga fasa dan kontak-kontak listrik yang belum sempurna. Untuk menghindari gangguan tersebut diperlukannya sistem proteksi, salah satunya menggunakan rele differensial. Rele differensial ini bekerja dengan sangat cepat dan tidak memerlukan penundaan waktu (time delay) dengan cara mendeteksi perbedaan arus yang masuk melalui kumparan stator, apabila arusnya berbeda maka rele differensial akan bekerja. Tujuan penelitian ini adalah untuk menganalisis penyetelan rele differensial pada generator di PT PJB UBJ O\&M PLTU Rembang yang berpengaruh terhadap keandalan pembangkit. Metode yang digunakan pada penelitian ini adalah metode kuantitatif, dimana dalam metode ini dilakukan pendekatan penelitian yang banyak dituntut menggunakan angka dari pengumpulan data, pengolahan terhadap data, serta penampilan hasilnya. Hasil yang didapat dari penelitian ini setelan rele differensialnya sebesar 0,1804 A, yang berarti masih dalam keadaan baik, sehingga dapat menjalankan tugasnya sebagai sistem proteksi.
\end{abstract}

Kata kunci: Generator, Rele Differensial, Hubung Singkat, Sistem Proteksi 


\section{PENDAHULUAN}

Semakin meningkat dan majunya teknologi yang ada saat ini tidak akan lepas dari kebutuhan akan tenaga listrik. Keandalan sistem tenaga listrik untuk dapat menyalurkan listrik kepada konsumen mempunyai peranan yang sangat penting.

Salah satu yang memegang peranan penting pada pembangkit listrik dan penyaluran tenaga listrik pada suatu sistem tenaga listrik adalah generator. Generator dalam fungsinya memasok tenaga listrik ke sistem harus memiliki keandalan dan persiapan yang baik. Bahwa terjadinya gangguan pada generator tidak dapat dihindarkan. Adapun ganguan yang dapat terjadi pada generator misalnya kerusakan generator atau alat bantu generator, arus hubung singkat dan kontak-kontak listrik yang belum sempurna.

Dalam hal ini generator harus memiliki pengaman dari segala kemungkinan gangguan yang terjadi. Bila terjadi gangguan pada generator secepat mungkin gangguan tersebut dapat diatasi, sehingga mencegah kerusakan pada generator atau sistem. Hal ini sangat penting karena kerja generator bersifat kontinu / terus menerus, oleh karena itu diperlukan sistem proteksi yang dapat bekerja secara selektif, cepat dan handal yaitu salah satunya adalah rele differensial.

Rele differensial ini bekerja dengan sangat cepat dan tidak memerlukan penundaan waktu (time delay), sehingga rele ini dipilih sebagai pengaman yang utama. Rele differensial bekerja jika terjadi gangguan dalam daerah pengaman dan tidak bekerja jika terjadi gangguan luar daerah pengamananya. Apabila rele bekerja saat gangguan luar daerah pengamanannya, maka ini merupakan kejadian salah kerja yang dapat merusak peralatan.

Cara kerja rele differensial adalah apabila suatu keadaan gangguan di dalam daerah proteksinya dan terjadi perbedaan arus atau selisih arus yang melalui rele tersebut, maka rele ini akan bekerja. Rele ini tidak dapat bekerja apabila arus gangguan yang ditimbulkan kecil tetapi rele ini akan bekerja apabila arus yang ditimbulkan besar.

Karena itu, pada artikel ini akan membahas sistem proteksi generator, bagaimana perhitungan arus gangguannya dan kemudian memberikan penilaian terhadap setting rele differensial existing yang ada di PT. PJB UBJ O\&M PLTU Rembang.

\section{METODE PENELITIAN}

\subsection{Metode}

Metode yang digunakan dalam penelitian ini adalah pertama-tama kajian pustaka yang berkaitan dengan tema penelitian dan kemudian melaksanakan pengumpulan data, pengamatan dan pengujian terhadap obyek penelitian dilapangan. Data-data yang diperoleh dari hasil pengumpulan data dilakukan analisa dan pengolahan data dengan metode perhitungan dengan rumus-rumus berdasarkan dari kajian pustaka. Hasil perhitungan yang diperolah dibandingkan dengan hasil pengamatan dan pengujian yang diperoleh dilapangan sehingga bisa memberikan kesimpulan suatu proteksi masih berfungsi dengan baik atau tidak.

\subsection{Gangguan Arus Hubung Singkat}

Gangguan dalam sistem tenaga listrik merupakan hal yang tidak bisa dihindarkan. Gangguan sebagian besar merupakan hubung singkat dan mengakibatkan arus hubung singkat yang besarnya, umumnya lebih besar dibandingkan arus nominal peralatan yang mengalami gangguan. Sistem tenaga listrik selalu berkembang seirama dengan 
perkembangan beban. Perkembangan ini mempengaruhi besarnya arus gangguan pada setiap bagian dalam sistem. Oleh karenanya diperlukan perhitungan nilai arus hubung singkat diberbagai tempat dalam sistem untuk mendapatkan gambaran mengenai situasi arus hubung singkat, khususnya dalam kaitannya dengan penyetelan alat-alat pengaman atau rele.

Bila sebuah generator sinkron 3 fasa yang bergerak dengan kecepatan sinkron dan menghasilkan arus medan konstan, tiba-tiba ketiga fasanya mengalami hubung singkat atau short circuit, hubung singkat terjadi pada terminal stator.

Pada siklus pertama arus $I_{a}$ menurun secara drastis, dikenal sebagai subtransient period. Selama beberapa siklus berikutnya, arus menurun agak lambat dan batasan ini disebut transient period. Akhirnya arus mencapai nilai tetap. Arus ini masing-masing dibatasi oleh reaktansi subtransient $x_{a}^{\prime \prime}$, reaktansi transient $x_{a}^{\prime}$ dan reaktansi sinkron $x_{d}$ atau $x_{s}$. Reaktansi subtransient pada dasarnya disebabkan oleh adanya hambatan redam, reaktansi transient menunjukkan lilitan medan, reaktansi sinkron merupakan reaktansi akibat lilitan angker. Sesuai dengan rumus :

$$
I_{a}= \pm V_{o}\left[\left(\frac{1}{x_{d}^{\prime \prime}}-\frac{1}{x_{d}^{\prime}}\right)^{\mathrm{e}^{-\frac{\mathrm{t}}{\tau^{\prime} \mathrm{d}}}}+\left(\frac{1}{x_{d}^{\prime}}-\frac{1}{x_{d}}\right)^{\mathrm{e}^{-\frac{\mathrm{t}}{\tau / \mathrm{d}}}}+\frac{1}{x_{d}}\right]
$$

dimana : $\tau^{\prime \prime} d=$ Subtransient waktu konstan

$\tau^{\prime} d=$ Transient waktu konstan

$V_{o}=$ Tegangan fasa angker hubungan terbuka

\subsection{Bagian-bagian Generator yang Diamankan}

\subsubsection{Belitan Stator}

1. Gangguan Hubung Singkat Tiga Fasa

Jenis gangguan tiga fasa simetris merupakan gangguan yang paling berbahaya bagi generator, karena besarnya arus hubung singkat yang terjadi dalam belitan ini dapat menimbulkan pemanasan lebih, sehingga dapat mengakibatkan kebakaran mesin. Arus hubung singkat yang terjadi dibatasi oleh besarnya GGL dan reaktansi generator.

Dari bentuk arus hubung singkat diatas dapat diketahui bahwa generator sinkron memiliki 3 macam reaktansi, yaitu :

a. Reaktansi Sub Peralihan ( $\left.X^{\prime \prime}\right)$, yang berpengaruh pada saat terjadinya hubung singkat. Arus hubung singkat yang dipengaruhi oleh reaktansi sub peralihan ini mengalir hanya beberapa detik saja, yang besarnya adalah $I^{\prime \prime}=E / X "$. Arus ini dikenal dengan arus sub peralihan.

b. Reaktansi Peralihan ( $\left.X^{\prime \prime}\right)$, yang mempengaruhi besarnya arus hubung singkat selama periode peralihan. Reaktansi ini lebih besar dari harga reaktansi sub peralihan, sehingga arus hubung singkat peralihan lebih kecil dari arus hubung singkat sub peralihan $\left(I^{\prime}=E / X^{\prime \prime}\right)$.

c. Reaktansi Sinkron $(X)$, yang mempengaruhi arus hubung singkat dalam keadaan lunak atau steady state. Untuk menghitung arus hubung singkat yang 
terjadi pada suatu generator, digunakan suatu metode yang dikenal dengan Teori Komponen Simetris. Dimana dalam teori ini besaran arus dan tegangan fasa dinyatakan dalam besaran-besaran vektor komponen urutan positif, urutan negatif dan urutan nol.

Untuk gangguan hubung singkat fasa simetris, besar arus hubung singkat yang mengalir di setiap fasa adalah sama dengan urutan positif. Dalam kondisi simetris (seimbang), komponen-komponen vektor urutan negatif dan nol tidak ada.

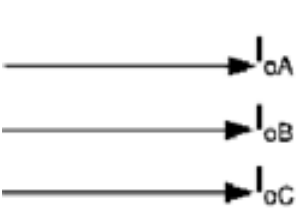

Zero Squence

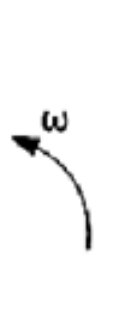

Gambar 1. Vektor Komponen Simetris

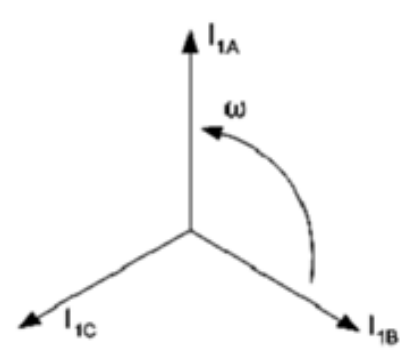

Positive Squence

$$
\begin{aligned}
& ; I_{a}=I_{a 1}+I_{a 2}+I_{a 0} \\
& ; I_{b}=a^{2} \cdot I_{a 1}+a \cdot I_{a 2}+I_{a 0}
\end{aligned}
$$

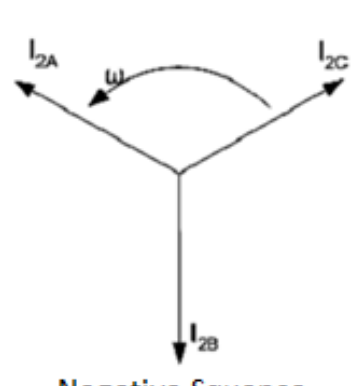

Negative Squence

$V_{b}=a^{2} \cdot V_{a 1}+a \cdot V_{a 2}+V_{a 0}$

(2)

$$
V_{c}=a \cdot V_{a 1}+a^{2} \cdot V_{a 2}+V_{a 0} \quad ; I_{b}=a \cdot I_{a 1}+a^{2} \cdot I_{a 2}+I_{a 0}
$$

2. Hubung Singkat Fasa ke Fasa

Gangguan hubung singkat fasa ke fasa suatu generator yang ditanahkan melalui impedansi Zn, hubungan jala-jala urutan untuk tiap-tiap komponen adalah paralel. Dalam hal ini komponen arus urutan nol tidak ada, karena pada tempat gangguan tidak terdapat hubung singkat ke tanah.

3. Hubung Singkat Fasa-fasa ke Bumi

Gangguan hubung singkat fasa-fasa ke bumi, ketiga jala-jala urutan terhubung paralel.

4. Hubung Singkat Fasa ke Bumi

Gangguan inilah yang mungkin terjadi dalam suatu mesin karena adanya kerusakan isolasi sehingga terjadi hubung singkat antar kawat fasa ke badan (ground). Dengan menggunakan teori komponen simetris pada gangguan hubung singkat ke bumi ini ketiga jala-jala urutan terhubung seri.

5. Kondisi Tidak seimbang

Pada saat sistem mengalami gangguan hubung singkat tidak simetris, berdasarkan teori komponen simetris arus mengalir dalam sistem terdiri dari tiga komponen urutan simetris, yaitu :
a. Arus urutan positif $I_{1}$
b. Arus urutan negatif $I_{2}$
c. Arus urutan nol $I_{0}$ 
Arus urutan negatif merupakan arus yang dihasilkan oleh suatu sistem 3 fasa yang arah putar fasornya berlawanan dengan arah perputaran fasor sistem urutan positif. Sedangkan arus urutan nol adalah komponen arus yang bukan berupa sistem tiga fasa. Ketiga arus nol memiliki fasa yang sama. Sehingga arus urutan nol pada mesin tidak ditransposisi akan terjadi ketidaksimetrisan yang kemudian timbul arus urutan negatif. Besarnya arus urutan negatif tergantung pada konfigurasi dan besarnya sistem.

\subsubsection{Belitan Rotor}

1. Pemanasan pada Belitan Rotor oleh Arus Urutan Negatif

Arus urutan negatif yang timbul akibat ketidakseimbangan sistem akan menimbulkan suatu medan putar pada stator yang arah putarannya berlawanan terhadap perputaran rotor dengan kecepatan $n=\frac{120 . f}{p}$. Gelombang putar arus urutan negatif ini akan menginduksikan arus putar pada bagian-bagian logam di rotor dengan frekuensi 2 kali frekuensi sistem. Sedangkan arus urutan negatif tidak menginduksikan arus putar pada rotor, karena medan putarnya berputar dengan arah dan kecepatan yang sama terhadap rotor. Demikian pula arus urutan nol pada stator tidak menginduksikan arus putar rotor karena komponen arus urutan nol ini bukan merupakan sistem tiga fasa yang dapat menimbulkan medan putar urutan nol. Arus rotor yang disebabkan oleh induksi arus urutan negatif tidak hanya mengalir dalam batang-batang peredam seperti halnya pada mesin induksi rotor sangkar, akan tetapi mengalir pada permukaan inti rotor, dinding alur rotor, belitan medan dan pasak alur (wedges).

Medan magnet urutan negatif berputar berlawanan putaran rotor menimbulkan gelombang listrik induksi dipermukaan rotor yang kemudian merambat ke inti rotor. Hal ini menyebabkan terjadinya pemanasan dipermukaan rotor oleh induksi arus urutan negatif, terjadi ketidakseimbangan sistem.

\section{Pemanasan Rotor oleh Induksi Eddy Current}

Generator yang berputar tidak sinkron pada harga slip (s) tertentu, seperti halnya pada teori mesin induksi maka rotor akan terinduksi arus Eddy Current. Arus Eddy Current ini akan bersirkulasi di ring penahan belitan medan, rangkaian medan, batang-batang belitan peredam, inti rotor dan pasak-pasak penahan belitan medan (wedges).

Arus-arus induksi berpulsasi dengan frekuensi sebanding dengan harga slip yang terjadi,

$$
\mathrm{f} 2=\mathrm{sf} 1
$$

$$
\begin{aligned}
& \text { dimana: } \mathrm{S}=\text { Slip } \\
& \mathrm{f1} \text { = Frekuensi jala-jala (stator) }
\end{aligned}
$$


Sebagaimana telah diterangkan sebelumnya bahwa gelombang medan magnet listrik yang diinduksikan oleh medan magnet dipermukaan rotor akan merambat sampai pada suatu kedalaman $\delta$ tertentu di rotor.

3. Belitan Rotor Hubung Singkat ke Bumi

Gangguan hubung singkat tunggal rotor ke bumi (badan rotor) tidak akan membahayakan generator, sebab belitan tidak dibumikan, akan tetapi hal ini akan memperbesar kemungkinan terjadinya hubung singkat di lokasi akibat tegangan induksi dalam medan oleh transient stator. Hubung singkat ini akan memotong arus ditempat gangguan, sehingga sebagian belitan medan seakan-akan terhubung singkat dan terjadi ketidakseimbangan fluksi terkonsentrasi pada satu kutub yang lain, kerapatan fluksi ini berkurang. Akibatnya akan terjadi ketidakseimbangan gaya-gaya yang kemudian dapat menimbulkan getaran kuat pada rotor. Getaran ini dapat merusak bantalan-bantalan dan peralatan lainnya.

\subsection{Pengertian dan Fungsi Proteksi Sistem Tenaga Listrik}

Sistem Proteksi tenaga listrik adalah sistem proteksi yang dipasang pada peralatanperalatan listrik suatu sistem tenaga listrik seperti generator terhadap kondisi abnormal operasi sistem itu sendiri. Kondisi abnormal itu dapat berupa antara lain: hubung singkat, tegangan lebih, beban lebih dan lain-lain. Dengan kata lain sistem proteksi itu bermanfaat untuk :

1. Menghindari ataupun untuk mengurangi kerusakan peralatan-peralatan akibat gangguan (kondisi abnormal operasi sistem). Semakin cepat reaksi perangkat proteksi yang digunakan maka akan semakin sedikit pengaruh gangguan kepada kemungkinan kerusakan alat.

2. Cepat meminimalisir gangguan yang terjadi menjadi sekecil mungkin.

3. Dapat memberikan pelayanan listrik dengan keandalan yang tinggi kepada konsumen dan juga mutu listrik yang baik.

4. Mengamankan manusia terhadap bahaya yang ditimbulkan oleh listrik.

Pengetahuan mengenai arus-arus yang timbul dari berbagai tipe gangguan pada suatu lokasi merupakan hal yang sangat penting. Jika terjadi gangguan pada sistem, para operator yang merasakan adanya gangguan tersebut diharapkan segera dapat mengoperasikan circuit-circuit breaker yang tepat untuk memisahkan pembangkit dan jaringan yang terganggu. Sangat sulit bagi seorang operator untuk mengawasi gangguangangguan yang mungkin terjadi dan menentukan CB mana yang dioperasikan untuk mengisolir gangguan tersebut secara manual.

Mengingat arus gangguan yang cukup besar, maka perlu secepat mungkin dilakukan proteksi. Hal ini perlu suatu peralatan yang digunakan untuk mendeteksi keadaan-keadaan yang tidak normal tersebut dan selanjutnya menginstruksikan circuit breaker yang tepat untuk bekerja memutuskan rangkaian atau sistem yang terganggu. Dan peralatan tersebut kita kenal rele.

\subsection{Rele Diferensial}

\subsubsection{Pengertian dan Prinsip Kerja Rele Differensial}

Prinsip kerja rele differensial tergantung pada adanya perbedaan arus yang masuk dan yang keluar dan bagian yang dilindungi, yaitu perbedaan arus dari dua buah trafo arus 
yang masuk ke rele. Pada rele differensial, diperlukan dua trafo arus yang dipasang di kedua sisinya, yaitu sisi masuk dan sisi keluar dan bagian yang dilindungi, seperti pada Gambar 3.

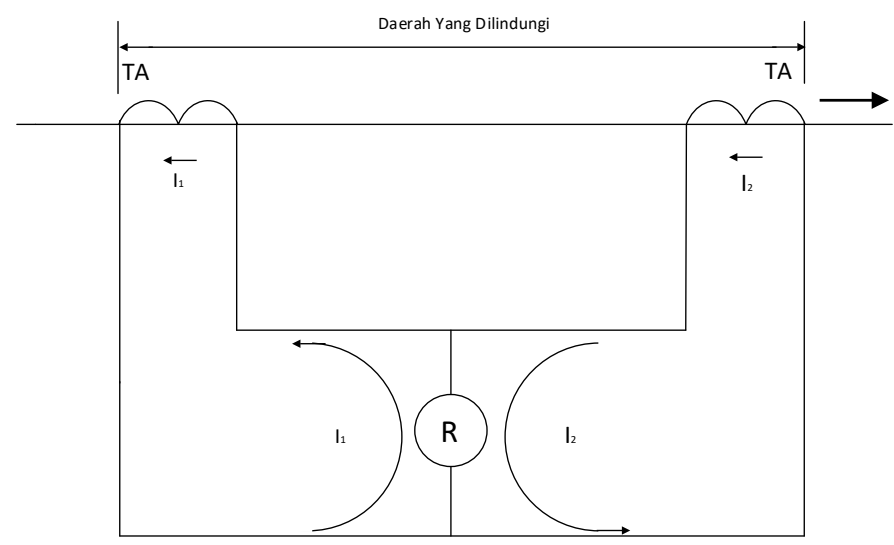

Gambar 2. Prinsip Kerja Rele Differensial yang Didasarkan pada Perbedaan Arus Sirkulasi

Rele R merupakan komparator sederhana yang membandingkan besaran arus, di kedua ujung dari daerah yang dilindungi.

\subsubsection{Rele Differensial Presentase}

Walaupun trafo arus identik, bila beban sekunder masing-masing trafo arus tidak sama, maka akan terjadi kejenuhan yang tidak sama. Beban yang tidak sama disebabkan oleh beberapa hal, yaitu:

1. Rele atau belitan kerja rele tidak terpasang pada titik equipotensial dan kawat penghubungnya.

2. Pada kawat penghubung terdapat sambungan ke alat lainnya.

Untuk mengatasi hal ini dapat ditempuh dengan rele differensial bias. Pada rele differensial bias terdapat dua kumparan penahan yang dialiri arus yang akan membangkitkan kopel penahan. Arus yang mengalir pada kumparan kerja rele adalah $I_{1}-$ $I_{2}$ dan arus yang mengalir pada kumparan penahan adalah $\frac{I_{1}-I_{2}}{2}$ dimana kedua kumparan penahan tersebut identik.

Pada keadaan rele tidak bekerja, gaya (kopel) kerja sama dengan gaya kopel penahan. Jadi, karakteristiknya mempunyai kecuraman yang ditentukan oleh perbandingan $\frac{\mathrm{Np}}{\mathrm{Nk}}$ atau untuk rele tertentu nilainya konstan per unit bias dan didefinisikan sebagai perbedaan arus dibagi dengan sirkulasi arus rata-rata dan perbandingannya konstan untuk semua besaran arus.

\subsubsection{Gangguan-gangguan yang Menyebabkan Rele Differensial Bekerja}

Diantara gangguan-gangguan yang menyebabkan rele differensial bekerja adalah,

1. Kerusakan lilitan stator generator karena sambaran petir.

2. Kerusakan lilitan stator generator karena adanya bagian dari rotor yang lepas dan menghantam lilitan stator.

3. Hubung singkat lilitan stator generator karena minyak pelumas atau air pendingin dari mesin penggerak bocor dan mengenai lilitan stator. 
4. Adanya binatang yang mengenai terminal lilitan stator generator.

5. Ujung-ujung kumparan stator terkena tekanan mekanis sehingga isolasinya rusak dan timbul hubung singkat antar lilitan stator.

\subsubsection{Proteksi Differensial Untuk Generator}

Sistem pengaman differensial pada generator berfungsi untuk mengamankan apabila terjadi gangguan hubung singkat di dalam generator. Pemasangan Transformator arus (CT) terletak pada sisi switchgear dan sisi titik netral generator. Dengan demikian bagian yang diamankan adalah kumparan stator generator tersebut sampai dengan kedua transformator arus yang terpasang tersebut. Sehingga jika terjadi gangguan hubung singkat dalam kumparan stator tersebut atau daerah yang diamankan rele differensial bekerja, yaitu dengan membuka pemutus tenaga (PMT) serta pemutus penguat transformator.

Pada Gambar 4 pemasangan rele differensial pada generator dan untuk mempermudah dibuat sistem pengaman satu fasa.

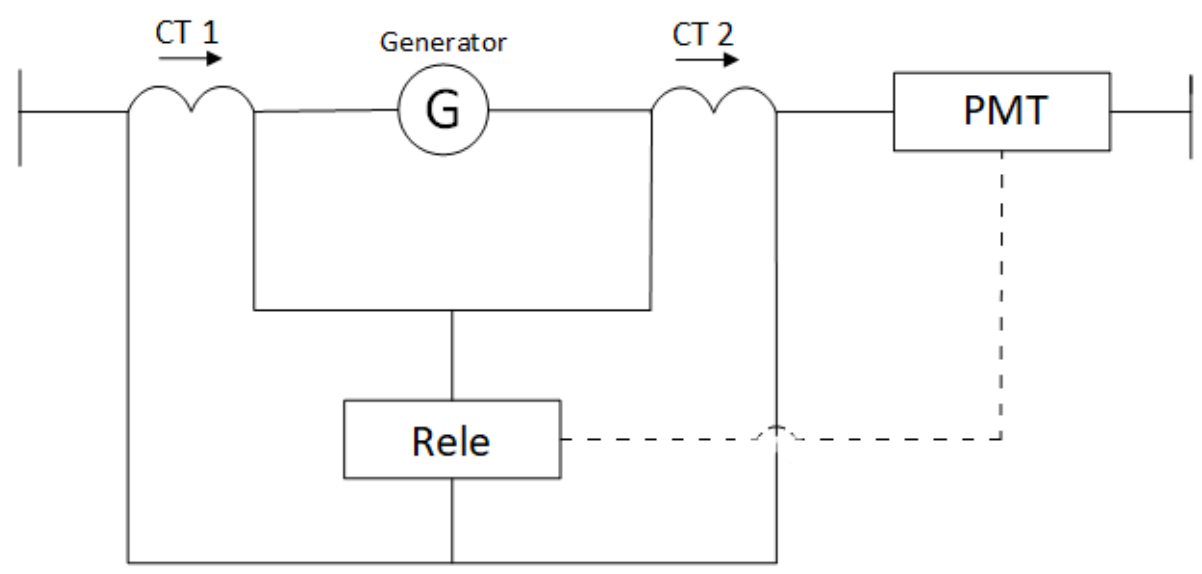

Gambar 3. Diagram Satu Fasa Pengaman Differensial pada Generator

Penggunaan rele differensial dengan sistem ini berfungsi untuk mendeteksi gangguan di dalam yang terjadi, seperti hubung singkat fasa ke fasa, fasa ke tanah dan hubung singkat antara belitan dalam fasa. Gangguan hubung singkat tersebut dapat dideteksi tergantung pada hubungan belitan kumparan stator.

\section{HASIL DAN PEMBAHASAN}

\subsection{Arus Gangguan pada Generator}

Data-data generator dan trafo berikut digunakan untuk melakukan perhitungan arus gangguan yang mengalir ke rele:

1. Generator

Merk

Belitan

Tegangan

Kecepatan

Daya

Reaktansi

Sinkron $\left(X_{d}\right)$
: Nanjing Nari

: Bintang $(\mathrm{Y})$

: $20 \mathrm{kV}$

$: 3000 \mathrm{rpm}$

: 353 MVA

$: 185,48 \%$ 


$\begin{array}{ll}\text { Transient }\left(X_{d}^{\prime}\right) & : 22,6 \% \\ \text { Subtransient }\left(X_{d}{ }_{d}\right) & : 15,58 \% \\ \text { Urutan Fasa Negatif }\left(X_{2}\right) & : 17,94 \% \\ \text { Nol }\left(X_{0}\right) & : 7,72 \% \\ \text { Rasio Trafo Arus 1 } & : 15000 / 5 \mathrm{~A} \\ \text { Rasio Trafo Arus 2 } & : 15000 / 5 \mathrm{~A} \\ \text { Cos } \phi & : 0,85 \\ \text { Frekuensi } & : 50 \mathrm{~Hz}\end{array}$

2. Data Tranformator Utama

Merk

: Areva

Daya

: 375 MVA

Konstanta Belitan Trafo

: $20 \mathrm{kV} / 150 \mathrm{kV}$

Impedansi

$: 14 \%$

Data-data generator dan trafo tersebut di atas digambarkan pada Gambar 4 berikut,

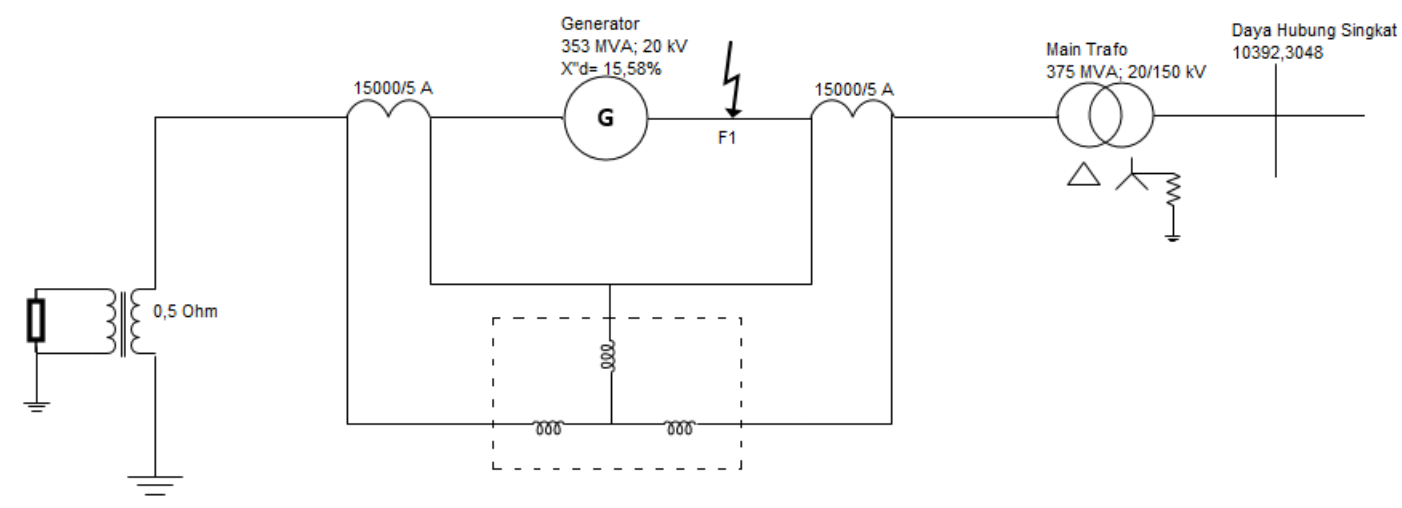

Gambar 4. Bagan Satu Garis Sistem

Dengan MVA Base adalah 100 MVA, maka arus dasar dapat diperoleh dengan menggunakan persamaan 4 berikut,

Arus dasar $=\frac{M V A_{\text {dasar }}}{\sqrt{3} x \text { Tegangan }}$

(4)

Sehingga, arus dasar $=\frac{100000 \mathrm{kVA}}{\sqrt{3} \times 20 \mathrm{kV}}=2886,751 \mathrm{~A}$

Impedansi dasar diperoleh dengan menggunakan persamaan 5 sebagai berikut,

$Z_{\text {dasar }}=\frac{\text { Tegangan }^{2}}{M V A_{\text {dasar }}}$

(5)

Sehingga, $Z_{\text {dasar }}=\frac{(20 \mathrm{kV})^{2}}{100 \mathrm{MVA}}=4 \Omega$ 
Pada saat subtransient $\left(X_{d}^{\prime \prime}\right)=15.58 \%$, maka nilai reaktansi generator $\left(X_{G}\right)$ dan reaktansi trafo diperoleh berdasarkan persamaan (6) dan (7) berturut-turut sebagai berikut,

$X_{G}=X_{d}^{\prime \prime} x \frac{M V A_{\text {Generator }}}{M V A_{\text {base }}}$

(6)

$X_{T}=Z x \frac{M V A_{\text {Trafo }}}{M V A_{\text {base }}}$

Sehingga nilai impedansi generator adalah $0,044 \angle 90^{\circ}$ p.u. dan impedansi trafo $0,037 \angle 90^{\circ}$ p. u. Daya hubung singkat pada sistem sisi $150 \mathrm{kV}$ diperoleh sebagai berikut:

$M V A_{s c}=\sqrt{3} \times 150 \times 40=10392,305 M V A$

Nilai impedansi sistem $\left(Z_{\text {sistem }}\right)$ didapatkan dengan menggunakan persamaan 8 berikut ini:

$Z_{\text {sistem }}=\frac{\text { Tegangan }^{2}}{M V A_{\text {sistem }}}$

(8)

diperoleh nilai $Z_{\text {sistem }}=\frac{(20 \mathrm{kV})^{2}}{10392,305 \mathrm{MVA}}=0,038 \Omega$

sehingga nilai impedansi sistem dalam per unit didapatkan dengan menggunakan persamaan 9 berikut:

$X_{S}=\frac{Z_{\text {sistem }}}{Z_{\text {dasar }}}$

Nilai impedansi per unit diperoleh $X_{S}=\frac{0,038 \Omega}{4 \Omega}=j 0,01 p . u$

Hasil yang diperoleh dari reakstansi generator $\left(X_{G}\right)$, reaktansi trafo $\left(X_{T}\right)$ dan reaktansi sistem dalam per unit $\left(X_{S}\right)$, maka impedansi pengganti dapat diperoleh dengan menggunakan persamaan 10 berikut,

$Z_{\text {pengganti }}=\frac{X_{G} x\left(X_{T}+X_{S}\right)}{X_{G}+X_{T}+X_{S}}$

(10)

Diperoleh nilai $Z_{\text {pengganti }}=0,023 \angle 90$. Besar arus gangguan yang mengalir ke rele pada lokasi gangguan adalah,

$I_{h s 3 \phi}=\frac{V}{Z_{\text {pengganti }}}$

Didapatkan $I_{h s 3 \phi}=43,995 \angle-90$ p. u. Jadi arus hubung singkat tiga fasa dalam ampere adalah : 
$I_{h s 3 \phi}=43,995 \angle-90$ p. u $\times 2886,751 \mathrm{~A}=127001,7442 \angle-90 \mathrm{~A}$ atau $127 \angle-90 \mathrm{kA}$.

Besar arus hubung singkat yang diberikan dari sumber generator adalah diperoleh dari persamaan 12 berikut,

$I_{h s 20 k V}=\frac{X_{T}+X_{S}}{X_{G}+X_{T}+X_{S}} x I_{h s 3 \emptyset}$

(12)

Didapatkan nilai arus hubung singkat dari sumber generator sebesar $65471,6489 \angle-90 \mathrm{~A}$ dan sisi sekunder trafo arus 1 mengalir arus sebesar $I_{s 1}=65471,649 \times \frac{5}{15000}=21,824 \mathrm{~A}$.

Besar kontribusi arus hubung singkat dari sistem sumber adalah diberikan oleh persamaan 13 berikut,

$I_{h s 20 k V}=\frac{X_{G}}{X_{G}+X_{T}+X_{s}} x I_{h s 3 \emptyset}$

(13)

Diperoleh nilai $61530,095 \angle-90 \mathrm{~A}$, dan sisi sekunder trafo arus 2 mengalir arus $I_{S 2}=$ $61530,095 \times \frac{5}{15000}=20,51 \mathrm{~A}$

Besar arus gangguan yang terjadi di titik $\mathrm{F} 1$, di dalam daerah pengaman rele differensial, konstribusi dari generator mengalir arus sebesar 21,824 A melalui trafo arus 1, sedangkan trafo arus 2 mengalir arus sebesar 20,51 A dari konstribusi sistem sumber.

Arus yang mengalir ke kumparan rele differensial sebesar $I_{d}=21,824 \mathrm{~A}-20,51 \mathrm{~A}=$ 1,314 A. Nilai arus tersebut melebihi besar arus penyetelan rele yakni sebesar 0,716 A, sehingga bila terjadi gangguan maka menyebabkan rele differensial bekerja, yang akan mengaktifkan PMT generator dan PMT medan penguat generator sehingga generator berhenti beroperasi.

\subsection{Karakteristik Rele Differensial}

Berikut adalah data rele differensial yang digunakan pada generator di PT PJB UBJ O\&M PLTU Rembang,

$\begin{array}{ll}\text { Merk } & : \text { Micom } \\ \text { Tipe } & : \text { P633 } \\ \text { Arus Nominal }\left(I_{\text {nom }}\right) & : 1 \mathrm{~A} \\ \text { Rasio trafo Arus 1 } & : 15000 / 5 \mathrm{~A} \\ \text { Rasio trafo Arus 2 } & : 15000 / 5 \mathrm{~A}\end{array}$

Karakteristik rele differensial mempunyai kecuraman (slope) yang ditentukan oleh perbandingan $\frac{(\mathrm{I} 1-\mathrm{I} 2)}{(\mathrm{I} 1+\mathrm{I} 2) / 2}=\frac{\mathrm{Np}}{\mathrm{Nk}}$ yang nilainya adalah konstanta untuk semua besaran arus. Besaran $\frac{\mathrm{Np}}{\mathrm{Nk}}$ dinyatakan sebagai presentase bias $6 \%$ dan $70 \%$.

Arus setting differensial sendiri didapatkan dengan menggunakan persamaan 14 berikut,

$I_{\text {setting }}=\%$ slope $x I_{\text {restrain }}$

(14)

Dan arus restrain sendiri dapat diperoleh dengan menggunakan rumus 15 berikut, 
$I_{\text {restrain }}=\frac{\text { Arus sekunder trafo arus } 1 I_{S 1}+\text { Arus sekunder trafo arus } 2 I_{S 2}}{2}$

Didapatkan $I_{\text {restrain }}=21,167 \mathrm{~A}$. Nilai slope diperoleh dengan persamaan 16 berikut,

$$
\begin{aligned}
& \% \text { slope } 1=\frac{I_{d}}{I_{r}} \times 100 \% \\
& \% \text { slope } 2=\left(\frac{I_{d}}{I_{r}} \times 2\right) \times 100 \%
\end{aligned}
$$

Sehingga nilai slope didapatkan $\%$ slope $1=\frac{1,314}{21,167} \times 100 \%=6,208 \%$ dan $\%$ slope $2=$ $12,416 \%$. Dengan demikian setelah arus restrain dan slope didapatkan maka arus setting dapat dihitung dengan menggunakan rumus 14 dan diperoleh $I_{\text {setting }}=$ $6,208 \% \times 21,167 A=1,314 A$.

Tabel 1. Hasil Perhitungan $I_{d}$ dan $I_{\text {setting }}$

\begin{tabular}{|c|c|}
\hline \multicolumn{2}{|c|}{ Hasil Perhitungan Arus dan Setting Rele Differensial } \\
\hline$I_{d}$ & $1,314 \mathrm{~A}$ \\
$I_{\text {restrain }}$ & $21,167 \mathrm{~A}$ \\
$\%$ slope 1 & $6,208 \%$ \\
$\%$ slope 2 & $12,416 \%$ \\
$I_{\text {setting }}$ & $1,314 \mathrm{~A}$ \\
\hline
\end{tabular}

\subsection{Gangguan Hubung Singkat 1 Fasa ke Tanah}

Diketahui tahanan pentanahan generator sebesar $R_{n}=0,5 \Omega$, dan impedansi dasar telah dihitung pada persamaan 12 didapatkan $Z_{\text {dasar }}=4 \Omega$. Sehingga impedansi generator dalam per unit dihitung sebagai berikut,

$R_{n}=Z_{n}($ dalam p.u $)=\frac{0,5 \Omega}{4 \Omega}=0,125 \mathrm{p} . \mathrm{u}$

$Z_{\text {ntotal }}=3 \times R_{n}=3 \times 0,125=0,375 \mathrm{p} . \mathrm{u}$

Reaktansi urutan fasa negatif $\left(X_{2}\right)=17,94 \%$

$X_{2}=0,1794 \times \frac{353 \mathrm{MVA}}{100 \mathrm{MVA}}=\mathrm{j} 0,633 \mathrm{p} . \mathrm{u}$

Reaktansi urutan nol $\left(X_{0}\right)=7,72 \%$

$X_{0}=0,0772 \times \frac{353 \mathrm{MVA}}{100 \mathrm{MVA}}=\mathrm{j} 0,273 \mathrm{p} . \mathrm{u}$

Besar gangguan fasa ke tanah pada titik gangguan F1 diperoleh impedansi total sebagai berikut,

Impedansi totalnya $=$ j0,044 p.u + j0,633 p.u $+(0,375$ p.u + j0,273 p.u $)$

$$
=0,375+j 0,95 \text { p.u }
$$

Jadi, $|\mathrm{Z}|=\sqrt{0,375^{2}+0,95^{2}} \angle \tan ^{-1} \frac{0,95}{0,375}$

$$
=1,021 \angle 68,459 \text { p.u }
$$


Besar arus gangguan yang mengalir ke rele pada lokasi gangguan adalah:

$I_{1}=I_{2}=I_{0}=\frac{\mathrm{V}}{|\mathrm{Z}|}=\frac{1}{1,021 \angle 68,459}=0,979 \angle-68,459 \mathrm{p} . \mathrm{u}$

Sehingga arus gangguan satu fasa ke tanah dalam ampere yang memberikan dampak pada generator adalah,

$I_{F G 1 \varnothing}=3 \times 0,979 \angle-68,459$ p.u $\times 2886,751 A=8478,388 \angle-68,459 A$

Dan arus gangguan tiga fasa dalam per unit yang mengair ke trafo sistem adalah,

$I_{\text {trafosistem }}=\frac{3 \times I_{1} \times\left(X_{T}+X_{S}\right)}{Z}$

(17)

Didapatkan nilai arus gangguan sebesar $I_{\text {trafosistem }}=$ $\frac{3 \times 0,979 \angle-68,459 \times\left(0,037 \angle 90^{\circ} \mathrm{p} \cdot \mathrm{u}+j 0,01 \mathrm{p} . u\right)}{1,021 \angle 68,459}=0,138 \angle-46,918 \mathrm{p}$.u. Sehingga arus satu fasa ke tanah dalam ampere yang memberikan dampak pada trafo sistem adalah, $I_{\text {trafosistem }}=0,138 \angle-46,918$ p.u $\times 2886,751 \mathrm{~A}=398,372 \angle-46,918 \mathrm{~A}$

Sehingga arus gangguan satu fasa yang mengalir pada sisi sekunder trafo arus 1 adalah $I_{s 1}=8478,388 \times \frac{5}{15000}=2,826 \mathrm{~A}$, dan pada sisi sekunder trafo arus 2 adalah $I_{s 1}=$ $398,372 \times \frac{5}{15000}=0,133 A$. Dengan demikian nilai arus differensial diperoleh nilai $I_{d}=$ $2,826 A-0,133 A=2,693 A$. Nilai arus differensial hasil perhitungan tersebut lebih besar dibanding nilai setting rele differensial terpasang yaitu $0,716 \mathrm{~A}$, sehingga nilai tersebut akan menyebabkan rele bekerja yang akan membuka PMT generator dan PMT medan penguat generator sehingga generator berhenti beroperasi.

Tabel 2. Hasil Perhitungan $I_{d}$ dan $I_{\text {setting }}$ Satu Fasa ke Tanah

\begin{tabular}{|c|c|}
\hline \multicolumn{2}{|c|}{ Hasil Perhitungan Arus dan Setting Rele Differensial } \\
\hline$I_{d}$ & $2,693 \mathrm{~A}$ \\
$I_{\text {restrain }}$ & $1,479 \mathrm{~A}$ \\
$\%$ slope 1 & $182,021 \%$ \\
$\%$ slope 2 & $364,165 \%$ \\
$I_{\text {setting }}$ & $2,693 \mathrm{~A}$ \\
\hline
\end{tabular}

\subsection{Setting Rele Differensial}

Setting rele differensial dengan arus nominal $1 \mathrm{~A}$ adalah diperoleh dengan menggunakan persamaan 18 berikut,

$I_{\text {nom }}=\frac{M V A_{\text {Trafo }}}{\sqrt{3} \times k V_{20 k V}}$

Sehingga didapatkan nilai arus nominal sebesar 10825,317 A. Jadi nilai arus pada sisi sekunder trafo arus 1 dihasilkan nilai, 
$I_{C T 1}=10825,317 \mathrm{~A} \times \frac{5}{15000}=3,608 \mathrm{~A}$, dan nilai arus pada sisi sekunder trafo arus 2 dihasilkan nilai,

$$
I_{C T 2}=10825,317 \mathrm{~A} \times \frac{5}{15000}=3,608 \mathrm{~A}
$$

Faktor kesalahan arus yang diakibatkan oleh kejenuhan magnetis dan perbedaan tahanan atau impedansi kabel yang menuju rangkaian pengaman differensial pada sisi sekunder, sebesar fct $=5 \%$. Sehingga diperoleh,

fct $=5 \% \times 3,6084=0,1804 \mathrm{~A}$

Arus differensial, $I_{d}=\left(I_{1}-I_{2}\right)+f c t$

$$
\begin{aligned}
& =(3,6084-3,6084)+0,1804 \mathrm{~A} \\
& =0,1804 \mathrm{~A}
\end{aligned}
$$

Maka penyetelan untuk arus minimum rele differensial diatur nilai sebesar 0,1804 $\mathrm{A}$.

Analisa CT yang digunakan adalah 100VA 0.5,5P20. 100 VA merupakan rating beban, class 0,5 adalah class $C T$ yang cocok untuk pengukuran. Artinya 0,5 disini adalah CT tersebut mempunyai error 0,5 untuk setiap langkahnya, jadi semakin kecil class maka semakin presisi CT tersebut, Class 5P20 adalah contoh class yang cocok untuk proteksi, artinya dari 5P20 disini adalah CT memiliki error 5\% dan 20 menjelaskan CT ini mampu dilewati arus $20 x$ arus nominalnya untuk menanggung arus gangguan. Jadi, error $5 \%$ pada saat $20 \times 5 A=100 A$ arus gangguan yang bisa ditanggung.

Analisa CT diatas dipergunakan untuk mengetahui besarnya kesalahan arus yang mengalir pada CT yang terpasang pada rele differensial, sehingga menjadi patokan nilai minimum pada settingan differensial, dimana rele differensial tersebut tidak akan bekerja ketika terjadi kesalahan arus yang disebabkan karena adanya error CT.

$$
\begin{aligned}
& \text { Mismatch }=0,5 \times \frac{\text { arus terkecil }}{5}=0,1314 \\
& \text { Minimal Setting }= \text { Error CT }+ \text { Toleransi + Mismatch } \\
&=5 \%+5 \%+13,14 \% \\
&=23,14 \%
\end{aligned}
$$

Nilai error pada CT yang diambil memiliki nilai positif dikarenakan jika error CT bernilai negatif akan mempengaruhi kerja rele differensial, dimana rele differensial akan langsung bekerja ketika keadaan sistem masih dalam keadaan normal.

Analisa penyetelan rele differensial dengan perhitungan dan dengan pengujian adalah :

1. Hasil pengujian

Untuk penyetelan rele differensial generator pada PT PJB UBJ O\&M PLTU Rembang adalah 0,716 A. Penyetelan ini didapat dengan menggunakan alat relay tester (penguji rele).

2. Hasil perhitungan

Dari hasil perhitungan di atas didapatkan penyetelan rele differensial adalah $0,1804 \mathrm{~A}$.

Terjadinya perbedaan penyetelan antara perhitungan dan pengujian ini disebabkan karena pada perhitungan ada faktor-faktor yang harus dimasukkan dalam menyetel rele differensial, seperti faktor kesalahan magnetis yang disebabkan oleh kejenuhan magnetis 
dan faktor kesensitifitasan rele differensial. Pada rele hasil perhitungan, rele akan bekerja saat arus yang mengalir ke kumparan lebih dari 0,1804 A.

\section{KESIMPULAN DAN SARAN}

Dari uraian pada bagian Hasil dan Pembahasan, maka dapat disimpulkan bahwa:

1. Berdasarkan hasil perhitungan dengan data yang ada di lapangan bahwa rele differensial pada generator PT PJB UBJ O\&M PLTU Rembang bekerja, sehingga sistem proteksinya masih dalam kondisi baik.

2. Pengaruh besar arus gangguan hubung singkat pada rele differensial :

a. Arus gangguan hubung singkat tiga fasa sebesar $127001,7442 \angle-90 \mathrm{~A}$. Arus yang mengalir ke kumparan rele differensial sebesar $\mathrm{ld}=1,314 \mathrm{~A}$. Arus ini lebih besar dari arus penyetelan sebesar 0,1804 A, sehingga rele differensial bekerja.

b. Arus gangguan hubung singkat satu fasa ke tanah sebesar $8478,388 \angle-$ $68,459 \mathrm{~A}$. Dari perhitungan arus yang mengalir ke rele differensial sebesar $\mathrm{ld}=$ 2,693 A. Arus ini lebih besar dari arus penyetelan sebesar 0,1804 A, sehingga rele differensial bekerja.

3. Setelan rele differensial di PT PJB UBJ O\&M PLTU Rembang secara perhitungan yaitu sebesar 0,1804 A, dan hasil pengujian yang diperoleh dengan menggunakan alat relay tester adalah $0,716 \mathrm{~A}$.

\section{UCAPAN TERIMAKASIH}

Penulis mengucapkan terima kasih kepada PT PJB UBJ O\&M PLTU Rembang yang telah memberi dukungan yang membantu pelaksanaan penelitian ini dengan memberikan izin untuk pengamatan dan pengambilan data untuk penulisan artikel ini.

\section{DAFTAR PUSTAKA}

[1] Marsudi, D. (2006). Operasi Sistem Tenaga Listrik. Yogyakarta, Penerbit; Graha Ilmu.

[2] Marsudi, D. (2011). Pembangkitan Energi Listrik. (Ed. Kedua). Jakarta, Penerbit; Erlangga.

[3] Sarimun N, W. (2012). Proteksi Sistem Distribusi Tenaga Listrik (Ed. Pertama). Depok, Penerbit; Garamond.

[4] Iswanto, H. Bahan On Site Training Teknisi Pemeliharaan Proteksi PLTA. Mrica: PUSRI IB. Palembang: Politeknik Negeri Sriwijaya

[5] Yuniarto, Subari, A., Kusumastuti, D.H., (2015). Setting Relay Differensial Pada Gardu Induk Kaliwungu Guna Menghindari Kegagalan Proteksi. Transmisi, 17, (3), 2015, e-ISSN 2407 6422, 152.

[6] Fitriani, N.R., (2017). Analisis Penggunaan Relay Differensial Sebagai Proteksi Pada Transformator Daya 16 MVA Di Gardu Induk Jajar. Skripsi. Universitas Muhammadiyah Surakarta. 